\title{
HISTORIEN UTSTÄLLD
}

\author{
Bengt Lundberg
}

Är det samma historia som skolan lär ut och som visas i våra svenska museer? Det var på sätt och vis huvudfrågan och problemet i det museologiska forskningsprojekt som Per-Uno Agren tog initiativet till i slutet av 1980-talet och som vi tillsammans genomforde under första delen av 90-talet. Vi kom ämnes- och erfarenhetsmässigt från två olika båll. Den ene frän etnologi och museiverksambet, den andre frän skolfältet med lärarutbildning och senare forskarutbildning $i$ historia. Institutionen för museologi, da nyinrättad, framvuxen ur kulturvetarlinjen vid Umeå universitet, blev vår institutionella hemvist.

Det är viktigt att skilja på det förflutna, alltså allt det liv som utspelat sig före det nu vi lever $\mathrm{i}$, och historien som är olika berättelser om och rekonstruktionsförsök av skeenden och samband i det förflutna. Ordet 'historia' har grekiskt ursprung med betydelsen 'undersökning'. Undersökningarna har länge inom historieforskningen inriktat sig på att kartlägga hur de politiska förhållandena utvecklades inom olika statsbildningar och folk, demos, liksom relationerna mellan dem - inte minst de krig som fördes. Sålunda skriver Herodotos, 'historiens fader', om grekernas kamp mot perserna under tidigt 400-tal f.Kr. och behandlar Thukydides Atens strider med Sparta under senare delen av samma århundrade. De använde sig av såväl skriftliga som muntliga källor. Dessa undersökningar läggs efter varandra i kronologiska serier till vad som brukar kallas historieskrivning, dvs. en generaliserande historisk framställning oftast utgående från en statsbildning, t.ex. 'svensk historia'.

Museerna redovisar också 'hur det var en gång'. Det är intressant att konstatera att den materiellt berättade historien, som ju är museernas framställningssätt, är ungefär jämgammal med den skrivna historien. Det äldsta kända museet fanns i Babylon på 500-talet f.Kr. och innehöll fornsaker, där en del då redan var omkring 2000 år gamla. Men den museitradition som uppstår och utvecklas framför allt under senare delen av 1800-talet och fram till vår tid har ett helt annat berättarfokus än den skrivna historien. Museernas 'undersökningar', deras visuella framställningar ur det förflutna, deras 'historiebilder', utgår från etnos, dvs. hur folket på en plats, i ett landskap eller land format sina kulturer.

De museer vi undersökte var Bohusläns, 
84 Hälsinglands, Smålands och Landskrona museer som skildrar sina resp. folkgruppers liv och leverne i basutställningar med ambitionen att ge en bild av det förflutna. Dessa 'etnos' i olika trakter beskrivs indirekt genom de redskap och verktyg deras försörjning krävt, sätten att bo, äta, resa osv. Människorna bakom föremålen anas i gestalt av dockor, bilder eller från senare tid fotografier och filmer. Intressant är att dessa handlingar - att arbeta, bo, äta, klä sig - när de utförs idag ses som sociala data, men i museerna när de alltså hänförs till det förflutna förvandlas till 'kultur'. Delvis sammanhänger det med att de svenska museerna i så hög grad präglas av de kulturvetenskapliga ämnena arkeologi, etnologi och konstvetenskap. Denna ämnesdominans eller mer provokativt uttryckt - ämnesdiktatur - i museerna påverkar i hög grad samlingarnas sammansättning, därmed utställningarnas innehåll, liksom i viss mån deras form.

Utställningarna påverkas också kronologiskt och tematiskt av den struktur den traditionella utbildningen byggt in i svenskt museiväsende. Detta framträder tydligt i de basutställningar vi undersökt. Först kommer en arkeologisk del som skildrar stenåldersliv, oftast en boplats, i några fall 'stenyxor på rad' i montrar, dvs. den schablonbild som många använder när de uttrycker sitt ogillande av museer. Ett par av museerna, Hälsinglands museum och Smålands museum, har en viss representation av mellanliggande perioder fram till de etnologiska avsnitten som täcker de två senaste seklen. Dessa blir tämligen fylliga, men har en betoning av jordbruk, hantverk, borgerliga miljöer, dräkter och stadsnäringar. Vissa lokala nyckelpersoner skildras genomgående i alla museer. De senaste årtiondena är inte medtagna, trots att samtliga museer har målbeskrivningar med formuleringar av typen 'då, nu, sedan'.

Bohusläns museum går längst $\mathrm{i}$ renodling av en gles tidsrepresentation. Här är det i det närmaste 10000 år mellan 'den arkeologiska tidens' slut och 'den etnologiska tidens' början. Det närmaste nuet man kommer är en utställning om 1960talet med en avståndstagande attityd till det som där skildras i motsats till den välvilliga identifikationen med de äldre perioderna. Landskrona museum var det enda av museerna som täckte såväl dåtid, nutid som framtid. Det gjordes i den ekologiska utställningen 'Mellan istiderna' som producerades under vår undersökningsperiod. Vid ett senare återbesök hade framtidsdelen emellertid tagits bort med motiveringen att den inte fungerade.

Vi kunde konstatera att de granskade museerna $\mathrm{i}$ allt väsentligt hade ett bakåtblickande perspektiv, liksom flertalet andra svenska kulturhistoriska museer enligt vår erfarenhet. Detta perspektiv är knappast överraskande, eftersom det uttrycks just i begreppet kulturhistoria och stöds av en lång museitradition. Ambitionerna att vidga perspektivet mot nutid och framtid är tämligen nya och tycks ha stannat i en normativ ansats.

En annan iakttagelse var att flertalet basutställningar hjälpligt lyckades integrera de kulturhistoriska museernas 'grundämnen' arkeologi och etnologi, men så gott som alltid hänvisade det tredje, konstvetenskapen, till en separat konstexponering. Vi fann två smärre undantag. Det ena i Landskrona, där man utgått från prostdottern Nell Waldens livsöde, hennes giftermål med Herwarth Walden, och där- 
med fătt in en närkoppling till Europas intellektuella och konstnärliga avantgarde under tidigt 1900-tal. Här knyts konsten samman med individer och ett vidare samhälleligt skeende som ger en förklarande kontext. Detta var det mest lyckade exemplet. I Bohusläns museums basutställning, i delen som handlar och kvinnors liv och arbete, har man använt naivisten Bernhardssons tavlor som åskådningsmaterial.

Vi genomförde vår undersökning $\mathrm{i}$ tre steg, där det första redan är summariskt beskrivet. Det var vår egen analys av basutställningarna, till vilken en kortfattad redovisning för museernas framväxt ansluter.

Det andra steget byggde dels på måloch verksamhetsprogram, dels på intervjuer med producenterna samt annan dokumentation från utställningarnas tillkomst. Avsikten var att spegla intentionerna bakom utställningarna, men också den museipedagogik som kompletterade museets historieförmedling.

Påfallande var iakttagelsen, att museerna - som har som en av sina framträdande uppgifter i att dokumentera sin omvärld var så svaga när det gällde att dokumentera det egna arbetet med utställningsproduktion. Detta är knappast något unikt för denna form av intellektuellt arbete. Hur dokumenteras i själva verket forskningsarbetets mer kreativa faser? Det finns i allmänhet vare sig kamera eller bandspelare närvarande när idéerna föds och om så vore skulle dessa kreativitetens tankespån knappast synts eller hörts. De är varianter av tyst kunskap i egentlig mening.

Det mest fruktbärande inslaget var intervjuerna med utställningsproducenterna som gjordes återkommande vid 3-4 tillfällen med tidsmellanrum som varierade mellan ett par månader och ett år. Dessa intentionsintervjuer var naturligtvis lättast att genomföra $\mathrm{i}$ de fall där utställningarnas tillkomst låg nära $\mathrm{i}$ tiden. Det gällde främst Bohusläns och Landskrona museer. I Landskrona pågick t.o.m arbetet med 'Mellan istiderna' och våra intervjuer fick därmed en dokumenterande karaktär.

Varför gör man (bas)utställningar överhuvudtaget?

Här finns flera svar, men grundläggande är att man har samlingar som visas med utställningen som medium. Museer gör av tradition utställningar och framför allt personalen upplever efter viss tid (vanligen decennier) utställningarna som föråldrade och vill förnya dem. Det kan ha kommit forskningsresultat som gör utställningarna omoderna. Nya formspråk tränger fram inom branschen och ställer krav på förnyelse. Samhällsförändringar eller nya personalkonstellationer, t.ex. ny chef eller ny utställningsansvarig orsakar förändringar. Nytt material eller nya frågor till gammalt material ger impulser till nya historiska berättelser. Ett helt nytt museum byggs (Bohuslän) och nya utställningar blir ett följdkrav. Eller var orsakssambandet det omvända - nya utställningar behövdes och det blev då naturligt att bygga ett nytt museum?

Det tredje steget $\mathrm{i}$ vår analys var att komma åt besökarnas förståelse och upplevelse av utställningarna, dvs. utställningarnas reception.

Receptionsintervjuerna gjordes med tre olika kategorier:

- besökare som befann sig inne i museet,

- besökare som befann sig på annan plats och övertalades att göra ett museibesök tillsammans med oss, 
- «icke-besökare» som befann sig på annan plats och inte lät sig övertalas till ett besök, men som ändå lät sig intervjuas om sin syn på det närliggande museet och museer $\mathrm{i}$ allmänhet.

Inte minst den tredje kategorin som ofta tillhörde den stora grupp (drygt 50\%) som under året inte besöker ett museum var intressant. Dock hade de alltid under sin skoltid besökt något museum. Vi träffade i varje fall inte på någon som var helt utan museierfarenhet.

Intervjuerna med de två första grupperna gick så till att besökarna uppmanades att ta den väg som de brukar genom utställningen eller, om det är ett förstagångsbesök, den väg som de spontant ville välja. Vi bad intervjupersonerna 'tänka högt' om vad de såg, men vi ställde också frågor, observerade beteenden och reaktioner. Vår strävan var att underordna oss besökarens sätt att tänka och uppleva.

Besökarna hade med sig en förförståelse av historien som de fått ur olika källor. En var naturligtvis skolans historieundervisning, som mängdmässigt för de flesta hade försteg framför den museiberättade historien. Trots nedskärningar i timplaner handlar det ändå om ca en lektionstimme per vecka under hela skoltiden. En historia som de tillägnat sig genom bokläsning och lärarnas berättande. Lärare som utbildats i historia. På frågan om vad deras skolhistoria handlat om svarade flertalet - oberoende av ålder: 'kungar, krig och årtal'. En delvis annan förförståelse har de fått genom populärkulturen: historiska romaner, tecknade serier, filmer, rollspel (ofta i medeltidsmiljö), Hermans historia i TV osv.

Med dessa historiebilder, dessutom ofta uppblandade med äldre människors berättelser om hur det var förr, kommer besö- karna till museet och möter museernas historiebilder som mer är bilder av arkeologisk och etnologisk kunskap.

De kommer alltså med den i huvudsak traditionella historiens grundtema, som handlar om hur av många etnos - smålänningar, upplänningar, dalmasar, skåningar m.fl. - blir ett folk, demos, under Gustav Vasa och hur denna statsbildning under den följande stormaktstiden under bl.a. Gustav II Adolf vinner nya områden, som förloras under de två följande seklen. Ett Sverige som förändras från ett agrart ståndssamhälle till ett industriellt klassamhälle och slutligen blir demokratiskt, styrt av fem partier, med starka folkrörelser som samspelar med ett effektivt näringsliv och samverkar i god Saltsjöbadsanda för uppbyggnaden av Folkhemmet.

Denna huvudsakligen i skrift förmedlade historia handlar alltså om hur en maktägande elit, ALFA-strukturen, lägger under sig ett territorium, Sverige. Under det senaste århundradet sker en maktförskjutning. Folket, BETA-strukturen, blir herrar $i$ eget hus.

Denna historieskrivning som flertalet besökare har som gemensam referensram, har få beröringspunkter med museernas historiebilder, som i allmänhet undviker maktperspektivet och som utgår från lokala och regionala områden och som berättar utifrån livsvärldens perspektiv. Besökarna har mera sällan studerat de ämnen som ligger till grund för framställningen. De har så gott som aldrig fått lära sig 'att läsa en utställning'.

Resultatet blir - trots allt - när besökaren är museivan, välutbildad och begåvad, en förståelse som till stor del överensstämmer med producentens intentioner.

I många fall blir det rejäla missförstånd 
blandade med partiell förståele och i ytterligare andra blir det ingen förståelse alls.

Besökarens reception kan ses som ett kontinuum som sträcker sig från total överensstämmelse till partiell förståelse och partiellt missförstånd till misstolkning och ingen tolkning alls.

Den i alltför många fall uteblivna eller begränsade förståelsen av utställningarna uppvägdes till viss del av museibesökets upplevelsekvaliteter. Igenkännandets glädje, förundran, samhörighet med en trakt, rent av identifikation med den av museet presenterade kulturhistorien. Men svårigheten att förstå minskar genom att skolundervisningen gett historiebilder från en riksnivå högt däruppe, där olika grupperingar kämpat om herraväldet eller den abstrakta makten. Detta ändrades ingalunda med det källkritiska genombrottet i historieforskningen. Det är samma arena som utforskas, men aktörernas nobla motiv ifrågasätts. De senaste decenniernas alltmer differentierade historieforskning har nya inriktningar som socialhistoria, demografi, kvinnohistoria, lokalhistoria, mentalitetshistoria osv. Denna forskning ligger nära museernas nivå och här skulle skriven och materiell historia kunna mötas. Men denna sorts bredbandshistoria närmare de flesta människors erfarenheter har bara delvis nått in i läroplanerna. Den reduceras ytterligare i läromedlen och filtreras därefter genom en lärarkår som fostrats $\mathrm{i}$ en mer traditionell historieundervisning. Barnens reception påverkas genom föräldrars historieförståelse som varande 'kungar, krig och årtal'. Och i TV härskar Herman.

Gemensamt för undervisningsväsendets historia om demos och museernas om etnos är att de har svårt att hantera den näraliggande tiden. De rör sig tryggast i det traditionella samhället, där skolan skildrar ALFA-strukturen och museerna BETA-strukturen. Det moderna samhällets komplexa uppbyggnad vållar problem som gör att den näraliggande tiden undviks, problem som definitivt tilltar när den moderna tiden glider in i ett tilltagande postmodernt tillstånd någonstans från 1970 och framåt.

Det postmoderna tillståndet bryter utvecklingen från etnos till demos. Det präglas av att samhället - i betydelsen 'hålla samman' - upplöses och nya etnos bildas medan demos försvagas. Bara ca 15 medier mot i praktiken två (tal och skrift) för 100 år sedan och den ökande kanalklyvningen gör att gemensam kunskap, gemensamma värden och en sammanhållande kultur försvinner. Andra faktorer som globalisering, arbetes och kapitals fria rörelser, invandring, överstatliga organ som EU, de ständigt arbetslösa, nya regioner som Örestad, Balticum och Nordkalotten, bidrar till en ny etnifiering.

Flertalet av dessa nya etnos är i motsats till de gamla inte lokalt bundna. De knyts ofta samman av medier. Exempel på sådana mer eller mindre globalt täckande etnos eller 'stammar' från de senaste decennierna är punkare, yuppies, datanördar och nätsurfare, New Age-anhängare, Hiphopare, Spice Girlswannabees, nynazister och antirasister, backpackers etc. etc.

En annan tendens är en tilltagande generasism, alltså en ökande fientlighet mellan olika åldersgrupper, där dessutom generationsårsringarna tätnar. Länge ansågs en generation omfatta ca 30 år, idag är det stora skillnader mellan 17åringar och 23-åringar, som dessutom ytterligare delas av olika subkulturer eller 
88 nyetnos 'horisontellt' inom sin åldersgrupp.

Den civilisationsprocess som såväl den skrivna historien som museerna skildrar som ett grundtema på var sina nivåer håller på att ersättas av en process i motsatt riktning, en decivilisering.

Möjligen kan de två kulturerna - historieforskningens textbundna makthistoria och museernas visuellt tecknade kulturhistoria mötas inför de hot och möjligheter vår tid erbjuder.

Vårt samhälle och demokratin skulle vinna på det.

Föreläsning i Köbenhamn inom ramen för Museumshøjskolens museologiska föreläsningar i mars 1998.

\section{SUMMARY}

History exhibited

The paper describes a research project carried out at the Department of Museology, Umeå University, the aim of which was to compare Swedish history as taught in the schools and as told in the exhibitions of four regional and municipal museums. The discrepancy between the political history approach in school books and the regional and local history exhibited in the museums is evident. Its cause is probably to be found in the 'nature' of the museum, with its cultural history approach based on an archaeological and ethnological analysis of material remains from the past. The national perspective abruptly confronts a local perspective and often - due to the traditional training of the schoolteachers using the exhibitions - it is difficult to reconcile them to each other in a meaningful way. Interviews with museum visitors show that the resulting view of the past is normally a mixture of information from many sources which is projected onto the exhibition rather than an acceptance of the interpretations offered in the texts that accompany the objects. The paper concludes by suggesting that closer collaboration between museum curators and researchers representing contemporary branches of history such as gender oriented and social history now established at universities might enhance the quality and coherence of history as told in museum exhibitions.

Bengt Lundberg är FD $i$ bistoria och prefekt for museologiska institutionen vid Umeå universitet. Adr Institutionen for museologi, Umeå universitet, S-901 87 Umeå

Fax $+46-90166672$ 